\title{
Hemophagocytic Lymphohistiocytosis and Atypical Uremic Syndrome Associated with Weil Syndrome
}

\author{
Nuria Citlalli Luna-Silva1, Alexis Gomez-Pardo', Heliodora Jimenez-Hernandez², \\ Victoria Isabel Castañeda-Avila ${ }^{3}$, Cesar Daniel Alonso-Bello ${ }^{*}$ \\ ${ }^{1}$ Pediatrics Department, Hospital de la Niñez Oaxaqueña, Oaxaca, Mexico \\ ${ }^{2}$ Hematology Laboratory, Hospital de la Niñez Oaxaqueña, Oaxaca, Mexico \\ ${ }^{3}$ Gynecology and Pediatrics 3A Hospital, Instituto Mexicano del Seguro Social, Mexico City, Mexico \\ ${ }^{4}$ Angeles Roma Hospital, Angeles Medical Group, Mexico City, Mexico \\ Email: *cesar_alonso86@hotmail.com
}

How to cite this paper: Luna-Silva, N.C., Gomez-Pardo, A., Jimenez-Hernandez, H., Castañeda-Avila, V.I. and Alonso-Bello, C.D. (2021) Hemophagocytic Lym-phohistiocytosis and Atypical Uremic Syndrome Associated with Weil Syndrome. Open Access Library Journal, 8: e7464. https://doi.org/10.4236/oalib.1107464

Received: April 28, 2021

Accepted: June 28, 2021

Published: July 1, 2021

Copyright $\odot 2021$ by author(s) and Open Access Library Inc.

This work is licensed under the Creative Commons Attribution International License (CC BY 4.0).

http://creativecommons.org/licenses/by/4.0/

(c) (i) Open Access

\begin{abstract}
In 1886, the German internist Adolph Weil described for the first time a disease caused by the spirochete family of the genus Leptospira spp., causing the infectious disease called leptospirosis or Weil Syndrome in a systemic stage. The disease is transmitted by direct contact with infected animals, which eliminates the bacteria through urine or by contact with the soil and water where they live. Hemophagocytic Lymphohistiocytosis (HLH) or hemophagocytic syndrome, is a syndrome caused by immunological activation involving different organs. It has also been documented, as a cause of Atypical Hemolytic Uremic Syndrome (aHUS) rarely. In this report, we describe an extremely rare clinical presentation of leptospirosis (Weil Syndrome), associated with HLH and aHUS, an association with great clinical relevance. The syndrome that until today has not been described is the first case report, made formally in the medical literature.
\end{abstract}

\section{Subject Areas}

Infectious Diseases, Internal Medicine

\section{Keywords}

Leptospirosis, Hemophagocytic, Lymphohistiocytosis, Hemolytic Uremic Syndrome

\section{Introduction}

In 1886, the German internist Adolph Weil described for the first time a disease 
caused by the spirochete family of the genus Leptospira spp., causing the infectious disease called leptospirosis or Weil Syndrome in a systemic stage. Although it is a disease characterized by occurring in tropical environments, cases have been reported in different countries without this climate [1]. The disease is transmitted by direct contact with infected animals, which eliminates the bacteria through urine or by contact with the soil and water where they live. Hemophagocytic Lymphohistiocytosis (HLH) or hemophagocytic syndrome, is a syndrome caused by immunological activation involving different organs. It is characterized by infiltration of the bone marrow with lymphocytes and macrophages with hemophagocytic activity. This pathological process can be primary or secondary (acquired) and the etiology is diverse, it can be of infectious origin; mainly due to viruses, however, diseases such as leptospirosis are related to the development of HLH.

Yang et al., reported two cases of leptospirosis associated with LHH in 1997 [2]. In 2013, Krishnamurthy et al. [3] and Jevtic et al. [4], reported cases of pediatric patients with this association. In 2017, Warley et al. [5] carried out a cohort study in which the results showed the association of a case with this pathology, to date they are the only cases of HLH associated with leptospirosis and reported in the literature. Infection with Leptospira spp. has also been documented, as a cause of Atypical Hemolytic Uremic Syndrome (aHUS) rarely, these reports were made in 1985, by Hanvanich et al. [6] and in 2009 by Iragorri et al. [7], the most recent by Muthuppalaniappan et al. in 2018 [8].

In this report, we describe an extremely rare clinical presentation of leptospirosis (Weil Syndrome), associated with HLH and aHUS, an association with great clinical relevance. The syndrome that until today has not been described is the first case report, made formally in the medical literature.

\section{Case Presentation}

A 5-year-old schoolboy from Oaxaca, Mexico, as the only important antecedent, in his daily life, has exposure to farm cattle.

His current condition began on May 9, 2019, with a fever of up to 40 degrees Celsius from 10 days of evolution, the symptoms were accompanied by a purple lesion in the neck, and arthralgias in the knees. On physical examination, he presented head deviation to the right, difficulty to ambulation, and language alteration. He received medical attention and the diagnosis of chickenpox was made, treatment with paracetamol and loratadine was started without clinical improvement. In the complementary studies, thrombocytopenia was documented. The patient had clinical deterioration. At the moment of the hospitalization is documented sepsis and multiple organ failure, he was transferred to the third level hospital.

At the time of admission, the patient was found to be stuporous and presented a generalized purpuric maculopapular rash, palpebral edema, neck stiffness, hepatomegaly $4 \mathrm{~cm}$ below the costal margin, as well as edema of the pelvic limbs as 
shown in Figure 1. Central nervous system infection by Streptococcus pneumoniae was suspected. The blood count and initial studies on admission are shown in Table 1. The diagnostic study was complemented with lumbar puncture and analysis of cerebrospinal fluid, the results are shown in Table 2.

$\mathrm{He}$ was treated with intravenous meropenem $680 \mathrm{mg}$ every 8 hours (40 $\mathrm{mg} / \mathrm{Kg} / \mathrm{dose})$, intravenous vancomycin, $255 \mathrm{mg}$ every 6 hours $(60 \mathrm{mg} / \mathrm{Kg} / \mathrm{day})$. The clinical course evolved to shock, adrenaline $(0.04 \mu \mathrm{g} / \mathrm{Kg} / \mathrm{min})$, dobutamine $(5 \mu \mathrm{g} / \mathrm{Kg} / \mathrm{min})$ and dopamine $(4 \mu \mathrm{g} / \mathrm{Kg} / \mathrm{min})$ were administered. Due to a history of lumbar puncture results, a simple computed tomography of the skull was performed, showing subarachnoid hemorrhage.

Given the deterioration of the patient, management by the intensive care unit (ICU) was necessary. Based on the clinical evolution and laboratory results, HLH was suspected, for which additional studies were requested (Table 3). In the hematology evaluation, bone marrow aspiration, a Shiga toxin test, as well as ADAMTS13 activity was performed (Table 3 ). The patient was treated with intravenous human immunoglobulin $\mathrm{G}(2 \mathrm{~g} / \mathrm{kg} / \mathrm{dose})$, dexamethasone $\left(8 \mathrm{mg} / \mathrm{m}^{2}\right)$, and fresh frozen plasma, $(15 \mathrm{ml} / \mathrm{kg} /$ dose $)$ every 12 hours.

On the second day of hospital stay in ICU, the acute kidney injury persisted. Rheumatology and nephrology evaluation, rule out autoimmune disease. With the normal result of ADAMTS13 activity, the atypical hemolytic uremic syndrome is diagnosed. In search of an infectious focus and a history of exposure, serology was requested for Leptospira spp.

With the serological results and findings in bone marrow as shown in Figure 2, the diagnosis of HLH and aHUS, due to Weil's Syndrome, was determined. Treatment with cephalosporin and the HLH2004 protocol was started.

After treatment, the patient had a good clinical response. One week later bone marrow aspiration was performed again, reporting decreased cellularity in $20 \%$ (normal range $30 \%-70 \%$ ), decreased megakaryocytes only 3 cells (normal range 5 - 10 per microscopic field); myeloid series with a report of lymphocytes $81 \%$ (normal 8.6\% - 23.8\%), monocytes 3\% (normal 0\% - 0.6\%), bands 3\% (normal $9.4 \%-15.4 \%$ ), segmented $13 \%$ (normal $13.1 \%$ - 30.1\%), without evidence of hemophagocytosis.

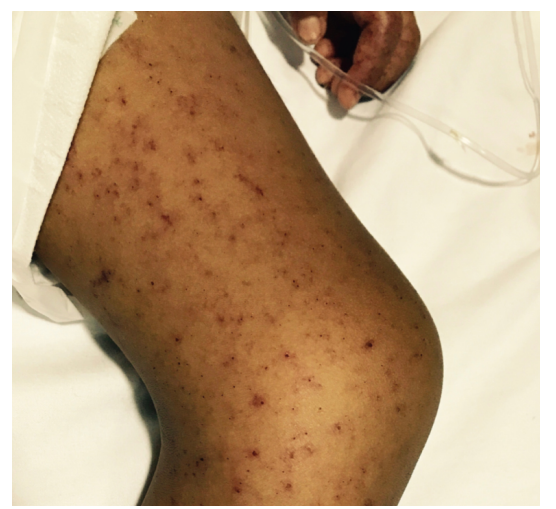

Figure 1. Maculopapular rash, with purpuric lesions, at hospitalization time. 
Table 1. Laboratory studies upon admission of the patient to hospitalization.

\begin{tabular}{cc} 
Hemoglobin & $12.9 \mathrm{~g} / \mathrm{dl}(11.5-14 \mathrm{~g} / \mathrm{dl})$ \\
Platelets & $10 \times 10^{3} / \mu \mathrm{l}\left(150-400 \times 10^{3} / \mu \mathrm{l}\right)$ \\
Leukocytes & $22.3 \times 10^{9} / \mathrm{l}\left(5.0-17.0 \times 10^{9} / \mathrm{l}\right)$ \\
Lymphocytes & $27 \%, 6.0 \times 10^{9} / 1\left(1.5-9.5 .0 \times 10^{9} / \mathrm{l}\right)$ \\
Neutrophils & $89 \%, 19.8 \times 10^{9} / \mathrm{l}\left(1.0-8.5 .0 \times 10^{9} / \mathrm{l}\right)$ \\
Creatinine & $1.1 \mathrm{mg} / \mathrm{dl}(0.5-1.0 \mathrm{mg} / \mathrm{dl})$ \\
Fibrinogen & $180 \mathrm{mg} / \mathrm{dl}(200-400 \mathrm{mg} / \mathrm{dl})$ \\
Triglycerides & $420 \mathrm{mg} / \mathrm{dl}(<150 \mathrm{mg} / \mathrm{dl})$ \\
Ferritin & $7512 \mu \mathrm{g} / \mathrm{l}(7-140 \mu \mathrm{g} / \mathrm{l})$ \\
\hline
\end{tabular}

Table 2. Cerebrospinal fluid analysis.

\begin{tabular}{cc} 
Cells & $155 \mathrm{cel} / \mathrm{mm}^{3}$ \\
Leukocytes & $15 \mathrm{cel} / \mathrm{mm}^{3}$ \\
Polymorphonuclear & $6 \%$ \\
Mononuclear & $94 \%$ \\
Erythrocytes & $140 \mathrm{cel} / \mathrm{mm}^{3}$ \\
Crenocytes & $80 \%$ \\
Ph & 7.8 \\
Glucose & $118 \mathrm{mg} / \mathrm{dl}$ \\
Lactic dehydogenase & $95 \mathrm{mg} / \mathrm{dl}$ \\
Proteins & $189.26 \mathrm{mg} / \mathrm{dl}$ \\
Lactate & $2.8 \mathrm{mmol} / \mathrm{l}$ \\
\hline
\end{tabular}

Table 3. Immunological studies performed on the patient.

\begin{tabular}{cc}
\hline IgA & $249 \mathrm{mg} / \mathrm{dL}(32-178 \mathrm{mg} / \mathrm{dl})$ \\
IgG & $1760 \mathrm{mg} / \mathrm{dL}(280-1108 \mathrm{mg} / \mathrm{dl}$ \\
IgM & $1010 \mathrm{mg} / \mathrm{dL}(42-227 \mathrm{mg} / \mathrm{dl})$ \\
C3 & $128 \mathrm{mg} / \mathrm{dL}(588-1589 \mathrm{mg} / \mathrm{dl})$ \\
C4 & $22 \mathrm{mg} / \mathrm{L}(78-372 \mathrm{mg} / \mathrm{dl})$ \\
Anti-ADAMTS13 IgG & $27.4 \mathrm{IU} / \mathrm{mL}(35.6-158 \mathrm{IU} / \mathrm{ml})$ \\
ADAMTS13 activity & $59 \%(50 \%-160 \%)$ \\
\hline
\end{tabular}




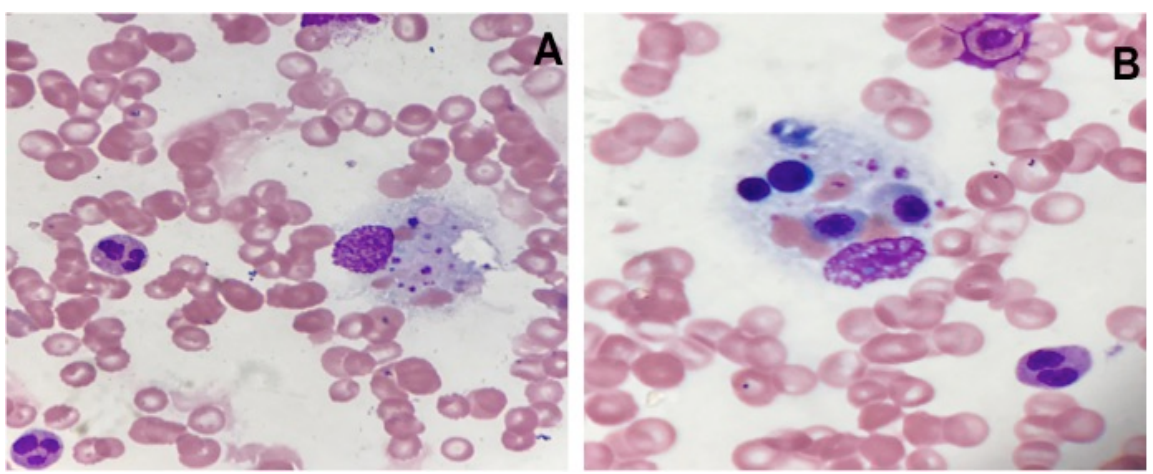

Figure 2. Microscopic view of the bone marrow aspirate, with 100x magnification and May-Grünwald Giemsa staining. Panel A shows an absence of megakaryocytes, a cellular predominance of neutrophils with toxic granulations. Panel B shows monocytes with vacuoles, and activated macrophages.

\section{Discussion}

Polymorphonuclear Neutrophils (PMNs) are important cells for the proper elimination of Leptospira spp. In Vitro studies have shown a slow growth of these organisms and since these organisms are extracellular, they require opsonizing antibodies for their adequate elimination in addition to the activation of the classical pathway of the complement system [9] [10]. The surface proteins of Leptospira spp. have been identified as virulence determinants, these include surface proteins, lipopolysaccharides, motility, chemotaxis, and secretory proteins. An example is the LipL32 protein that triggers the inflammatory response at the level of the cells renal proximal tubule of mice through mechanisms of TLR-2 and NF-kB activation [11].

HLH has been associated with various bacterial and fungal infections, neoplasms, vascular, and collagen diseases. In these cases, splenic macrophages present an activated phenotype, with increased expression of MHC class I and II molecules and increased expression of the M-CSF receptor. It is also known that excessive activation of phagocytic cells is due to high levels of activating cytokines such as INF-g, IL-2R, TNF-a, IL-1, IL-6 [12]. We have previously described how, in leptospira infections, virulence determinants are responsible for the inflammation and secretion of cytokines that can trigger HLH in some patients.

Complement activation can be carried out in three ways: detection of foreign antigens and activation of the alternative pathway, activation of the classical pathway by antibodies, or activation of the lectin pathway by mannan polysaccharides. These pathways lead to the formation of large amounts of C3b in the cell membrane and cause the activation of $\mathrm{C} 5$, which culminates in the formation of the membrane attack complex and cell lysis, when this happens at the renal level, the lesions are caused by aHUS features [13].

It has been shown that up to $60 \%$ of patients with aHUS are carriers of mutations in complement regulatory genes, for example, CFH, MCP, CFI, THBD, or components of $\mathrm{C} 3$ convertase, Factor $\mathrm{B}$ and $\mathrm{C} 3$, these mutations are related to 
dysregulation in the alternate activation pathway [14]. Until now, it has not been possible to carry out a genetic study in the patient in the clinical case, but during the follow-up, he has not developed any alterations at the renal level again.

In the clinical case presented, the patient presented jointly with aHUS with HLH related to leptospirosis that was evidenced by serology. The diagnosis of aHUS was made, by demonstrating that ADAMTS13 activity remains adequate. HLH was verified with bone marrow aspiration. In the international literature, few reported cases of aHUS related to an infection by Leptospira spp. exist. HLH is a pathology related to various infections, even in tropical countries [15]. However, we are not aware of case reports of Weil Syndrome, presented jointly with aHUS, this is the importance of making this case report internationally.

In this clinical case, it is important to recognize that the manifestation of infection by Leptospira spp., can manifest with the classic symptoms, however, there are a few cases that can present with excessive activation of the immune response, which instead of fighting the infection, causes organic damage due to the important secretion of pro-inflammatory interleukins. Recognition of the atypical clinical signs and symptoms that may accompany a widely known infection may be the cause of the disease itself and be strongly associated. The physician must be trained to recognize these atypical manifestations of the disease.

With this information, we conclude that Leptospira spp. infection is a triggering factor for HLH and aHUS. This is caused by the significant secretion of interleukins that is triggered by inflammation related to virulence factors recognized to date. By sharing our experience, we contribute to understanding pathophysiological processes, broadening the diagnostic approach, and proposing specific treatments for these pathologies.

\section{Conflicts of Interest}

The authors declare no conflicts of interest regarding the publication of this paper.

\section{References}

[1] Kumakura, S. (2005) Hemophagocytic Syndrome. Internal Medicine, 44, 278-280. https://doi.org/10.2169/internalmedicine.44.278

[2] Yang, C.W., Pan, M.J., Wu, M.S., Chen, Y.M., Tsen, Y.T., Lin, C.L., et al. (1997) Leptospirosis: An Ignored Cause of Acute Renal Failure in Taiwan. American Journal of Kidney Diseases, 30, 840-845. https://doi.org/10.1016/S0272-6386(97)90091-3

[3] Krishnamurthy, S., Mahadevan, S., Mandal, J. and Basu, D. (2013) Leptospirosis in Association with Hemophagocytic Syndrome: A Rare Presentation. The Indian Journal of Pediatrics, 80, 524-525. https://doi.org/10.1007/s12098-012-0863-0

[4] Jevtic, D., Djokic, D., Redzic, D., Aleksic, D., Parezanovic, M and Pasic, S. (2018) Secondary Hemophagocytic Lymphohistiocytosis in a Child with Leptospira Infection: A Case Report. The Turkish Journal of Pediatrics, 60, 735-738. https://doi.org/10.24953/turkjped.2018.06.016

[5] Warley, F., Bonella, B.N., Odstrcil-Bobillo, M.S., Otero, V., Waisman, G., Bendel- 
man, G., et al. (2017) Clinical Characteristics and Mortality of Adult Patients with Hemophagocityc Syndrome: Retrospective Cohort Study. Revista Médica de Chile, 145, 344-350. (Original in Spanish) https://doi.org/10.4067/S0034-98872017000300008

[6] Hanvanich, M., Moollaor, P., Suwangool, P. and Sitprija, V. (1985) Hemolytic Uremic Syndrome in Leptospirosís Bataviae. Nephron, 40, 230-231.

https://doi.org/10.1159/000183465

[7] Iragorri, S. and Tullus, K. (2009) Leptospirosis Mimicking Hemolytic Uremic Syndrome: A Case Report. American Journal of Kidney Diseases, 54, 721-725. https://doi.org/10.1053/j.ajkd.2009.01.274

[8] Muthuppalaniappan, V.M., Rajakariar, R. and Blunden, M.J. (2018) Leptospirosis Presenting as Haemolytic Ureamic Syndrome: A Case Report. BMC Nephrology. 19, Article No. 20. https://doi.org/10.1186/s12882-018-0817-5

[9] Jost, B.H., Adler, B., Vinh, T. and Faine, S. (1986) A Monoclonal Antibody Reacting with a Determinant of Leptospiral Lipopolysaccharide Protects Guinea Pigs against Leptospirosis. Journal of Medical Microbiology, 22, 269-275. https://doi.org/10.1099/00222615-22-3-269

[10] Fraga, T.R., Barbosa, A.S. and Isaac, L. (2011) Leptospirosis: Aspects of Innate Immunity, Immunopathogenesis and Immune Evasion from the Complement System. Scandinavian Journal of Immunology, 73, 408-419. https://doi.org/10.1111/j.1365-3083.2010.02505.x

[11] Palaniappan, R.U.M., Ramanujam, S. and Chang, Y.F. (2007) Leptospirosis: Pathogenesis, Immunity and Diagnosis. Current Opinion in Infectious Diseases, 20, 284-292. https://doi.org/10.1097/QCO.0b013e32814a5729

[12] Fisman, D.N. (2000) Hemophagocytic Syndromes and Infection. Emerging Infection Diseases, 6, 601-608. https://doi.org/10.3201/eid0606.000608

[13] Bienaime, F., Dragon-Durey, M.-A., Regnier, C.H., Nilsson, S.C., Kwan, W.H., Blouin, J., et al. (2010) Mutations in Components of Complement Influence the Outcome of Factor I-Associated Atypical Hemolytic Uremic Syndrome. Kidney International, 77, 339-349. https://doi.org/10.1038/ki.2009.472

[14] Campistol, J.M., Arias, M., Ariceta, G., Blasco, M., Espinosa, L., et al. (2015) An Update for Atypical Haemolytic Uraemic Syndrome: Diagnosis and Treatment. A Consensus Document. Nefrología, 35, 421-447. https://doi.org/10.1016/j.nefro.2015.07.005

[15] Pannu, A.K. and Sharma, N. (2016) Tropical Infection Induced Hemophagocytic Lympho-Histiocytosis. International Journal of Hematology and Blood Disorders, 1, 1-4. https://doi.org/10.15226/2639-7986/1/1/00101 